\section{Organic Mulch Impact on Vegetation Dynamics and Productivity of Highbush Blueberry Under Organic Production}

\author{
Nicole Burkhard and Derek Lynch ${ }^{1}$ \\ Department of Plant \& Animal Sciences, Nova Scotia Agricultural College, \\ 50 Pictou Road, Truro, Nova Scotia B2N 5E3, Canada
}

\author{
David Percival \\ Department of Environmental Science, Nova Scotia Agricultural College, \\ Truro, Nova Scotia B2N 5E3, Canada
}

\section{Mehdi Sharifi \\ Department of Plant \& Animal Sciences, Nova Scotia Agricultural College, 50 Pictou Road, Truro, Nova Scotia B2N 5E3, Canada}

Additional index words. compost, fruit quality, ground floor management, leaf NPK, pine needles, Vaccinium corymbosum, weed control

\begin{abstract}
A 2-year study in Nova Scotia examined the effectiveness of thickly applied organic mulches as a method of weed control in highbush blueberries (Vaccinium corymbosum L.), and assessed weed and mulch impact on crop growth, leaf nutrient concentration, yield, and quality under organic production management. Mulches, applied in-row at 20 -cm depth, included pine needles (PN), manure-sawdust compost (MC), and seafood waste compost (SC). Competition from weeds negatively affected crop growth and productivity, reducing canopy volume $(16 \%$ to $38 \%)$, leaf nitrogen concentration and berry yields (up to $92 \%$ ), number (up to $91 \%$ ), and specific weight (up to $21 \%$ ). Among mulches, PN proved to be the most effective in suppressing weed growth with $55 \%$ less and $73 \%$ less aboveground weed biomass compared with the control in 2005 and 2006, respectively, although PN productivity effects were much more modest. One year after application, PN lost some efficacy at suppressing weeds but was still superior to both composts. Distribution of weed species was substantially altered by mulch treatment. Both composts prevented some weed emergence (i.e., sheep sorrel), but weed seeds germinating in composts, especially SC, experienced prolific growth likely as a result of available nutrients in composts. No detrimental effects on short-term plant productivity were noted despite high $C: N$ ratios of $P N$ and $M C$ (72:1 and 48:1, respectively). Plant vigor and yield were typically higher for compost mulch treatments, especially in weed-free subplots, and composts provided more complete fertilization reflected in increased leaf tissue elemental (NPK) composition. Fruit soluble solid (sugar) content was found to be significantly lower in PN and MC compared with SC, whereas total phenolic content was unaffected by mulches. Mulch application can improve organic highbush blueberry productivity by improving soil properties, nutrient availability, and weed suppression; however, precautions should be taken to avoid excess nutrient loading and weed seed contamination of mulches.
\end{abstract}

Management of competing vegetation has long been a challenge in agricultural production and current problems persist, even with the widespread use of herbicides. In a survey of commercial North American blueberry producers, weed problems were cited in almost all production areas (Strik, 2006). Weed competition for water and nitrogen (N) caused reductions in rabbiteye blueberry growth and yield potential and delayed early growth in the spring (NeSmith and Krewer, 1995). In particular, weed management is crucial in young plantings when bushes are not fully established and most susceptible to competition (Hanson and Havens, 1992). Weed control is even more challenging in organic highbush blueberry (Vaccinium corymbosum L.) (HBB) production (Kuepper and Diver, 2004), and there is a need to determine feasible control methods for organic management.

In commercial HBB operations, pre- and postemergence herbicides (such as simazine, glyphosate, hexazinone, and terbacil) are used to control within-row weeds. However, some can cause injury to young plants (Hanson and Havens, 1992) and are restricted from use in certified organic production (Canadian General Standards Board/Standards Council of Canada, 2006). As an alternative, thickly applied organic mulches may be an effective cultural weed management option. Mulch thickness is an important consideration because the emergence of weed seedlings is inversely related to seed depth so the efficacy of weed control tends to increase with mulch thickness (Aldrich, 1984; OzoresHampton, 1998). Mulches inhibit weed growth by excluding light from the soil surface providing a physical barrier to weed seedling emergence (Bond and Grundy, 2001) and also may include mechanisms including the release of allelopathic chemicals (Duryea et al., 1999). With apples, studies have found that poultry litter and woodchip compost (Brown and Tworkoski, 2004) and wood chip and shredded paper mulch (Granatstein and Mullinix, 2008) provided effective weed control for 1 and 3 years, respectively, as well as significant insect and fungal pest management benefits (Brown and Tworkoski, 2004).

Organic amendments are an integral part of conventional HBB culture. Materials such as pine bark, peat, and sawdust are commonly used as a preplant soil amendment in new fields to increase the organic matter content of mineral soils (Kozinski, 2006), promote uniform root distribution (Spiers, 1986), and increase soil waterholding capacity and aeration (Haynes and Swift, 1986). Organic mulches are also applied as a $7-$ to $12-\mathrm{cm}$ layer after planting because they are ideal for regulating temperature and moisture extremes, two sources of environmental stress for HBB plants (Lord, 1992). Heavy applications of organic mulch for weed control can result in high salinity and impact on plant yield and growth and/or low or excess availability of nutrients and consequently fertility and environmental impacts (Kuepper and Diver, 2004; Yang et al., 2002). The level of impact is related to chemical composition and physical properties of the mulch.

Few studies have focused on organic production practices for HBB (such as nonchemical weed control and organic sources of $\mathrm{N})$ or have investigated the dual-purpose quality of mulches (weed control and enhancing crop performance) in this context. Therefore, the objectives of this study were to 1) test the efficacy of thickly applied mulches as a method of weed control for HBB production; and 2) assess the effect of thickly 
applied mulches on HBB growth, leaf nutrient concentration, yield, and crop quality under organic production practices.

\section{Materials and Methods}

Site description and experimental design. A 2-year field study was conducted over the period 2005 to 2006 in an established field of 5-year-old northern HBB (cv. Duke) at "Blueberry Acres," a commercial blueberry operation in the Annapolis Valley, Nova Scotia, Canada (long. $45^{\circ} 08^{\prime} \mathrm{N}$, lat. $64^{\circ} 30^{\prime}$ W). This experiment was conducted in an insolated subsection of this conventional farm, which was organically managed. The mineral soil at the site, modified in terms of $\mathrm{pH}$ and organic matter content at planting in 2002, consisted of a Debert sandy loam classified as Orthic Humo-Ferric Podzol (Typic Haplorthods in the U.S. classification system) (Holmstrom and Thompson, 1989). Plant (within-row) and row spacings were $1 \times$ $4.2 \mathrm{~m}$, respectively, and rows consisted of $1.2 \mathrm{~m}$ wide berms with $3 \mathrm{~m}$ of permanent sod between berms. Each subplot consisted of $4.5 \mathrm{~m}$ of row. Supplemental irrigation was provided by an overhead sprinkler system during drier conditions to maintain a minimum weekly precipitation of $25 \mathrm{~mm}$. Air temperature and precipitation were recorded by an automated data logger, air temperature probe, and tipping-bucket rain gauge (Campbell Scientific, Edmonton, Alberta, Canada) located $\approx 1 \mathrm{~km}$ from the site.

The experiment was arranged as a randomized complete block, split-plot design with five blocks (each comprising $55 \mathrm{~m} \times$ $1.2 \mathrm{~m}$ of row), six amendment (mulch and fertility) treatments (main plots), and two levels of weed management (subplots). The main plot amendment treatments included 1) unfertilized control; 2) ammonium sulphate (AS) fertilizer (21-0-0); 3) Nutri-Wave $^{\circledR}$ (NW) dehydrated, pelletized poultry manure (4-1-2); 4) pine-needle (PN) mulch (Pinus strobus L.); 5) horse manure and sawdust compost (MC) mulch; and 6) seafood waste compost (SC) mulch. Subplot unit was level of biweekly hand weeding ( \pm weeded) applied to five plants comprising each subplot. All crop data were collected from the three center plants and results presented as an average per plant. The experiment (Trial 1) was established in 2005 and repeated (Trial 2) in 2006 at an adjacent location in the same field. In addition, to evaluate carryover effects of amendments in the year after application, weed, crop productivity, and berry quality parameters were also measured in Trial 1 in 2006 (referred to as Trial $1_{\mathrm{R}}$ ).

Soil and amendment characterization. Before treatment application in 2005 (Trial 1) and 2006 (Trial 2), soil (0 to $15 \mathrm{~cm}$ ) samples were collected to characterize selected initial soil properties (Table 1). A composite sample per block $(\mathrm{n}=5)$, each comprised of 10 cores taken within 20 to $30 \mathrm{~cm}$ of the plant row, were collected and analyzed for texture, $\mathrm{pH}$, organic matter, and macro- and micronutrient content. Separate composite soil samples before treatment application were collected from 0 to $30 \mathrm{~cm}$ and extracted with $2 M \mathrm{KCl}$ (5:1 extractant:soil $\mathrm{v}: \mathrm{w}$ ratio) and analyzed for mineral $\mathrm{N}\left(\mathrm{NH}_{4}-\mathrm{N}\right.$ and $\mathrm{NO}_{3}-\mathrm{N}$ ) content colorimetrically by a segmented flown Auto-Flow Analyzer (Technicon Industrial Instruments, Tarrytown, NY) (Lynch et al., 2004). To gauge the short-term effect of mulches on soil $\mathrm{pH}$, soil $(0$ to $6 \mathrm{~cm})$ samples were collected on 10 July 2006 from under the three mulches and the control and $\mathrm{pH}$ determined using a $\mathrm{pH}$ conductivity meter (Model 220; Denver Instruments, Denver, CO) (Hendershot et al., 1993).

All amendments were applied in the spring by hand to the soil surface [4 to 10 May 2005 (Trial 1) and 29 Apr. 2006 (Trial 2)]. Total dry matter and $\mathrm{N}$ application rates are provided (Table 2). The organicapproved and inorganic, conventional fertilizer treatments (NW and AS, respectively)

were banded at a width of $0.6 \mathrm{~m}(0.3 \mathrm{~cm}$ to each side of the plant) to stay within the drip line of the plant canopy and were applied to supply $\mathrm{N}$ at a recommend rate of $30 \mathrm{~kg} \mathrm{~N} / \mathrm{ha}$ (Hanson et al., 1992). The plantavailable $\mathrm{N}$ from NW was assumed to be $50 \%$ of total $\mathrm{N}$ (Lynch et al., 2008). Mulch treatments were applied to provide an inrow cover $1.2 \mathrm{~m}$ wide at an approximate depth of $20 \mathrm{~cm}( \pm 2 \mathrm{~cm})$. The total volume (L) applied was recorded and converted to a mass basis by determination of bulk density and moisture content. Composite samples of mulch amendments were characterized with respect to physical and chemical properties according to Lynch et al. (2004) (Table 3).

The MC amendment was made on-site by the commercial blueberry farm operation. The SC and NW treatments consisted of commercially available products manufactured

Table 1. Selected initial soil characteristics of experimental sites.

\begin{tabular}{lrr}
\hline & \multicolumn{1}{c}{ Trial 1} & Trial 2 \\
\hline Organic matter $(\%)^{\mathrm{y}}$ & $5.0^{\mathrm{z}} \pm 0.7$ & $3.1^{\mathrm{z}} \pm 0.3$ \\
$\mathrm{pH}$ & $5.8 \pm 0.7$ & $5.2 \pm 0.1$ \\
$\mathrm{Silt}\left(\mathrm{g} \cdot \mathrm{kg}^{-1}\right)^{\mathrm{w}}$ & $131.0 \pm 2.0$ & $66.1 \pm 5.0$ \\
Sand $\left(\mathrm{g} \cdot \mathrm{kg}^{-1}\right)$ & $747.0 \pm 9.0$ & $691.0 \pm 12.0$ \\
Clay $\left(\mathrm{g} \cdot \mathrm{kg}^{-1}\right)$ & $122.0 \pm 7.0$ & $243.0 \pm 8.0$ \\
Ammonium $\left(\mathrm{mg} \cdot \mathrm{kg}^{-1}\right)^{\mathrm{v}}$ & $6.2 \pm 2.7$ & $3.1 \pm 0.39$ \\
Nitrate $\left(\mathrm{mg} \cdot \mathrm{kg}^{-1}\right)$ & $0.8 \pm 0.4$ & $3.5 \pm 0.52$ \\
Phosphorus $\left(\mathrm{mg}^{\mathrm{v}} \cdot \mathrm{kg}^{-1}\right)^{\mathrm{u}}$ & $103.6 \pm 13.4$ & $117 \pm 18.6$ \\
Potassium $\left(\mathrm{mg}^{\mathrm{k}} \mathrm{kg}^{-1}\right)$ & $251.6 \pm 36.3$ & $89.9 \pm 15.6$ \\
Calcium $\left(\mathrm{mg} \cdot \mathrm{kg}^{-1}\right)$ & $515.1 \pm 96.6$ & $464.7 \pm 64.9$ \\
Magnesium $\left(\mathrm{mg}^{\mathrm{k}} \cdot \mathrm{kg}^{-1}\right)$ & $166.2 \pm 40.4$ & $117.9 \pm 21.1$ \\
Sulfur $\left(\mathrm{mg} \cdot \mathrm{kg}^{-1}\right)$ & $22.6 \pm 2.1$ & $21.9 \pm 2.9$ \\
\hline
\end{tabular}

${ }^{\mathrm{z}}$ Values are means with $\mathrm{n}=5 \pm \mathrm{SD}$.

y Organic matter as determined by wet oxidation.

${ }^{\mathrm{x}} \mathrm{pH}$ measured in $0.01 \mathrm{M} \mathrm{CaCl} \mathrm{Cl}_{2}$ with a soil/solution ratio of $1: 2$.

wParticle-size distribution determined by the hydrometer method.

${ }^{v}$ Mineral $\mathrm{N}$ was extracted using $2 \mathrm{M} \mathrm{KCl}$ and measured colourimetrically by segmented flow autoanalyzer. uSoil-available phosphorus, potassium, calcium, magnesium, and sulfur content measured after Mehlich III extraction.

Table 2. Amendment nitrogen and dry matter application rates.

\begin{tabular}{|c|c|c|c|c|}
\hline \multirow[b]{2}{*}{ Treatment } & \multicolumn{2}{|c|}{ Rate applied (mg dry matter/ha) } & \multicolumn{2}{|c|}{ Total nitrogen applied $(\mathrm{kg} \mathrm{N} / \mathrm{ha})$} \\
\hline & 2005 & 2006 & 2005 & 2006 \\
\hline Control (unfertilized) & - & - & - & - \\
\hline Ammonium sulphate fertilizer (AS) & - & - & 30 & 30 \\
\hline Nutri-Wave ${ }^{\circledR}$ poultry fertilizer (NW) & - & - & 60 & 60 \\
\hline Pine needle mulch (PN) & 66 & 82 & 403 & 500 \\
\hline Manure and sawdust compost (MC) & 276 & 238 & 2,953 & 2,475 \\
\hline Seafood waste compost (SC) & 538 & 538 & 4,519 & 4,304 \\
\hline
\end{tabular}

Table 3. Physical and chemical characteristics of mulch amendments applied in 'Duke' highbush blueberry field in 2005 and 2006.

\begin{tabular}{|c|c|c|c|c|c|c|}
\hline \multirow[b]{2}{*}{ Parameter $^{\mathrm{x}}$} & \multicolumn{2}{|c|}{ Pine needles } & \multicolumn{2}{|c|}{ Manure compost } & \multicolumn{2}{|c|}{ Seafood compost } \\
\hline & 2005 & 2006 & 2005 & 2006 & 2005 & 2006 \\
\hline$\overline{\text { Dry matter }\left(\mathrm{g} \cdot \mathrm{kg}^{-1}\right)}$ & $700^{z}$ & 680 & 350 & 288 & 541 & 641 \\
\hline $\mathrm{C}: \mathrm{N}$ ratio & $73: 1$ & $72: 1$ & $48: 1$ & $43: 2$ & $22: 1$ & $23: 4$ \\
\hline Bulk density $\left(\mathrm{kg} \cdot \mathrm{m}^{-3}\right)$ & 70.0 & 80.0 & 570 & 560 & 980 & 810 \\
\hline $\mathrm{pH}$ & 3.60 & 4.01 & 6.90 & 6.40 & 7.25 & 6.60 \\
\hline Total phosphorus $\left(\mathrm{g} \cdot \mathrm{kg}^{-1}\right)$ & $\mathrm{ND}^{\mathrm{y}}$ & ND & 1.2 & 1.5 & 2.4 & 2.5 \\
\hline Total potassium $\left(\mathrm{g} \cdot \mathrm{kg}^{-1}\right)$ & ND & ND & 3.8 & 2.3 & 2.0 & 1.8 \\
\hline
\end{tabular}

${ }^{\mathrm{z}}$ Values are means with $\mathrm{n}=4$. With the exception of dry matter, all analyses are reported on a dry weight basis.

${ }^{\mathrm{y}} \mathrm{ND}=$ not determined.

${ }^{\mathrm{x}}$ Total $\mathrm{C}$ and $\mathrm{N}$ content determined by dry combustion (LECO CNS-1000); $\mathrm{pH}$ was measured in $0.01 \mathrm{M}$ $\mathrm{CaCl}_{2}$ with mulch/solution ratio of $1: 2$; total phosphorus and potassium content determined by inductively coupled plasma after nitric acid digestion of dried samples. 
by Envirem Technologies Inc. (Fredericton, New Brunswick, Canada) approved for use in certified organic systems. The feedstock materials for the SC were crab and lobster processing waste and coniferous bark waste from forestry operations. Both $\mathrm{MC}$ and $\mathrm{SC}$ composts used in each experimental year were obtained from the same on site stockpile of these materials. PN consisted of a "waste" material stockpiled annually by a nearby commercial campground.

Weed measurements. The degree of weed control provided by treatments was assessed by visual surveys of percent weed cover and by sampling aboveground weed biomass in nonweeded subplots. Weed cover surveys were performed twice per season, on 10 June and 5 Aug. 2005 and on 15 June and 16 Aug. 2006. The percent surface area covered by weeds was estimated visually by the same individual in three randomly placed $0.25 \mathrm{~m}^{2}$ quadrats (Brown and Tworkoski, 2004) and rated as either 0 (no weed cover), 1 ( $1 \%$ to $10 \%$ cover), 2 ( $11 \%$ to $20 \%$ cover), 3 ( $21 \%$ to $30 \%$ cover), 4 ( $31 \%$ to $40 \%$ cover $), 5$ ( $41 \%$ to $50 \%$ cover), 6 ( $51 \%$ to $60 \%$ cover), 7 (61\% to $70 \%$ cover), 8 ( $71 \%$ to $80 \%$ cover $)$, $9(81 \%$ to $90 \%$ cover $)$, or $10(91 \%$ to $100 \%$ cover). Aboveground weed biomass was collected postharvest on 29 Aug. 2005 and 10 Aug. 2006. All weeds within three randomly placed $0.25 \mathrm{~m}^{2}$ quadrats were clipped $1 \mathrm{~cm}$ from the soil or mulch surface, placed in cloth bags, and stored at $4{ }^{\circ} \mathrm{C}$. Within $2 \mathrm{~d}$ of collection, weed samples were separated and identified by species and fresh weights were recorded before recombining into "grass/ broadleaf" and "legume" categories for each plot for the purpose of weed $\mathrm{N}$ uptake determination (data not shown). Unidentified species were recorded as "other." Subsamples $(\approx 100$ to $200 \mathrm{~g})$ of each category were weighed and dried at $60{ }^{\circ} \mathrm{C}$ for $48 \mathrm{~h}$ to determine moisture content. Weed biomass (fresh weight) was used to calculate the relative biomass value for commonly found species as described by Caamal-Maldonado et al. (2001) (relative biomass = biomass of one species/biomass of total species $\times 100$ ).

In July 2006, a large quantity of Vetch spp. was removed by farm staff from nonweeded subplots to prevent the spread of blueberry scorch virus by aphids. Unearthed weeds were collected, fresh weights taken, and subsamples dried to have an estimate of total biomass removed. In Trial $1_{\mathrm{R}}, 24.8 \mathrm{~kg}$ dry matter (DM) of weeds was removed and only $5 \mathrm{~kg} \mathrm{DM}$ of weeds from Trial 2. As a result of this incident, weed samples from Trial $1_{R}$ were not separated into broadleaf, grass, and legume categories during weed biomass sampling in August, but instead recorded as total biomass per subplot.

Plant measurements. Plant canopy volume for each bush was measured by recording one height and two perpendicular width measurements (to the nearest centimeter) and calculating its cylindrical volume (Black and Zimmerman, 2002). Blueberry leaves were sampled for tissue nutrient analysis on 16 Aug. 2005 (Trial 1), 3 Aug. 2006 (Trial $1_{R}$ ), and 4 Aug. 2006 (Trial 2), $\approx 2$ weeks into the harvest (Strik and Hart, 1997). Twenty-five midshoot newest fully formed leaves on firstand second-year canes were collected per plant ( 75 leaves per subplot), dried at $60{ }^{\circ} \mathrm{C}$ for $48 \mathrm{~h}$, and ground to pass a $0.5-\mathrm{mm}$ screen using a Retsch Mill (Retsch GmbH \& Co., Hann, Germany). Subsamples were analyzed for $\mathrm{N}$ content by dry combustion using a CNS-1000 analyzer (LECO Corp., St. Joseph, MI; Black and Zimmerman, 2002). Macro- and micronutrient concentration were determined by nitric acid digestion (Zheljazkov and Warman, 2002) and analyzed by an inductively coupled argon plasma spectrometer (ICAP 61; Thermo Fisher Scientific Inc., Waltham, MA).

Sampling to determine berry number and yield (g) per plant as fruit yield components was measured between 5 Aug. and 2 Sept. 2005 in five harvests and from 17 July to 7 Aug. 2006 in three harvests (Shanmugam, 2005). All remaining berries were picked on the last harvest date. The number of fallen berries was recorded as well and included in the fruit yield and berry number data. Berries were counted and weighed in the field, placed in coolers, and subsequently stored at $-20^{\circ} \mathrm{C}$. Berry fresh weight was calculated by dividing yield by berry number for each plant. All berry data are presented as cumulative totals across all harvest dates and average of three plants per subplot.

Soluble solids and total phenolics in berries as indices of berry quality were measured in weeded subplots of Trial $1_{\mathrm{R}}$. To determine soluble solids, $\approx 150 \mathrm{~mL}$ of blueberries was placed in a beaker, mashed with a spoon to break up whole berries, and blended for $15 \mathrm{~s}$ in a blender (Waring Products Inc., Torrington, CT). The juice was filtered by pouring blended berries through a Buchner vacuum flask, fitted with Whatman \#4 filter paper, and soluble solids were determined using a refractometer (Fischer Scientific Company, Ottawa, Ontario, Canada) (Percival, 2006).

The Folin-Ciocalteau procedure, according to Slinkard and Singleton (1977), was used to determine total polyphenolic contents in berries from weeded subplots and was conducted under reduced light conditions. Approximately $50 \mathrm{~g}$ of berries per sample were used and the extraction solvent consisted of $95 \%$ methanol:0.1 $\mathrm{M} \mathrm{HCl}(85: 15)$. Samples were read at $765 \mathrm{~nm}$ in a Cary 100 ultraviolet Spectrophotometer (Varian Inc., Palo Alto, CA). Gallic acid standards (100, 200, 300, 400, and $500 \mathrm{mg}$ gallic acid/L deionized water) were used to calibrate the percent absorbance and results are expressed as milligrams of gallic acid equivalents per gram of fresh weight.

Statistical analysis. An analysis of variance was conducted for leaf tissue macronutrient analysis, weed, and berry quality parameters using the GLM procedure of SAS (Version 9.1, 2002-2003; SAS Institute Inc., Cary, NC). The Proc Mixed procedure was used for all other parameters for an analysis of variance of split plots (SAS Institute
Inc.). Analysis of variance was conducted separately for each trial year. Square root transformations were conducted on berry yield and numbers in 2005 and 2006 and on plant canopy volume and weeds biomass in 2006 to satisfy assumptions of normality and constant variance, which were verified using Proc Univariate (SAS Institute Inc.). Orthogonal contrasts were constructed to compare means when significant at $P<0.05$.

\section{Results}

Seasonal air temperature and precipitation. The 2005 and 2006 cumulative growing season rainfall (May to Nov.) was $658 \mathrm{~mm}$ and $607 \mathrm{~mm}$, respectively, which was greater than the 30-year seasonal average of $531 \mathrm{~mm}$ (Environment Canada, 2007). The highest monthly precipitation observed in 2005 was in May and Oct. and in 2006 was in June, July, and Oct., when over $100 \mathrm{~mm}$ of rain fell each month $(159,253,196,131$, and $111 \mathrm{~mm}$, respectively). The average seasonal daily air temperature in 2005 was 15.4 and $15.1^{\circ} \mathrm{C}$ in 2006 , comparable to the 30-year average of $14.7{ }^{\circ} \mathrm{C}$. The hottest months were July and Aug. 2005 and July 2006, reaching average daily air temperatures of $19.1,19.5$, and $21^{\circ} \mathrm{C}$, respectively.

Weed parameters. In all weed cover assessment dates, with the exception of June 2005, which followed a cool and wet spring, $\mathrm{MC}$ and $\mathrm{PN}$ ranked lower in their visual weed cover ratings than all other treatments (Table 4) and PN provided the most weed control benefit. In the carryover year after treatment application (Trial $1_{\mathrm{R}}$ ), PN was the only mulch treatment to reduce weed cover (Table 4).

When measured as postharvest weed biomass, the PN treatment was the most effective mulch in reducing weed growth, resulting in 55\% less and $73 \%$ less aboveground weed biomass compared with the control in 2005 and 2006, respectively (Table 4). In 2005, weed biomass in MC was $38 \%$ less than the control and was significantly different when contrasted with SC, which produced the highest weed biomass. There were no significant differences between AS and NW or between these treatments and the mulch treatments (Table 4). In the 2006 application year (Trial 2), there were no differences between the two composts or between the control and the amendments as a group. Instead, significant treatment contrast effects were the result of a low magnitude contrast between AS and NW and a high magnitude contrast between the PN and MC and SC (Table 4). Despite the unintended removal of Vetch spp. in Trial $1_{R}$, treatment effects still had a significant impact on weed biomass in the carryover year. One year after application, PN provided the best weed control with a $63 \%$ reduction in weed biomass compared with the unamended control (Table 4). Among the mulch treatments, PN resulted in significantly less (84\%) weed biomass than the two composts.

Predominant weed species, characterized for Trial 1 and Trial 2 only, were similar in 
Table 4. In-season weed cover and weed biomass at harvest as influenced by amendment treatment.

\begin{tabular}{|c|c|c|c|c|c|c|c|c|c|}
\hline \multirow[b]{3}{*}{ Treatment ${ }^{z}$} & \multicolumn{3}{|c|}{2005} & \multicolumn{3}{|c|}{2006} & \multicolumn{3}{|c|}{$2006\left(\right.$ Trial $\left.1_{R}\right)$} \\
\hline & \multicolumn{2}{|c|}{ Visual ranking } & \multirow{2}{*}{$\frac{\text { Weed biomass }}{\text { (kg dry matter/ha) }}$} & \multicolumn{2}{|c|}{ Visual ranking } & \multirow{2}{*}{$\frac{\text { Weed biomass }}{\text { (kg dry matter/ha) }}$} & \multicolumn{2}{|c|}{ Visual ranking } & \multirow{2}{*}{$\frac{\text { Weed biomass }}{\text { (kg dry matter } / \mathrm{ha})}$} \\
\hline & 10 June & 5 Aug. & & 15 June & 16 Aug. & & 15 June & 16 Aug. & \\
\hline Control & $3 \pm 1.9^{y}$ & $6 \pm 3.0$ & $1,815^{\mathrm{x}}$ & $8 \pm 1.4^{y}$ & $9 \pm 1.9$ & $1,642^{x}$ & $10 \pm 0.7^{y}$ & $10 \pm 0.2$ & $3,559^{x}$ \\
\hline AS & $5 \pm 2.6$ & $8 \pm 2.9$ & 2,979 & $7 \pm 1.7$ & $9 \pm 0.6$ & 1,246 & $10 \pm 0.3$ & $10 \pm 0.3$ & 2,586 \\
\hline NW & $5 \pm 3.0$ & $7 \pm 2.9$ & 2,463 & $7 \pm 2.2$ & $9 \pm 0.7$ & 2,005 & $9 \pm 2.7$ & $10 \pm 0.2$ & 3,588 \\
\hline $\mathrm{PN}$ & $4 \pm 2.9$ & $5 \pm 3.6$ & 808 & $2 \pm 0.3$ & $3 \pm 0.7$ & 448 & $6 \pm 2.1$ & $7 \pm 1.3$ & 1,300 \\
\hline $\mathrm{MC}$ & $3 \pm 2.5$ & $5 \pm 1.8$ & 1,122 & $3 \pm 1.3$ & $7 \pm 2.5$ & 2,607 & $9 \pm 0.7$ & $10 \pm 0.6$ & 2,608 \\
\hline $\mathrm{SC}$ & $3 \pm 2.0$ & $8 \pm 1.0$ & 5,137 & $10 \pm 0.7$ & $9 \pm 0.8$ & 3,122 & $10 \pm 0.2$ & $10 \pm 0.5$ & 4,244 \\
\hline Treatment & & & $* * *$ & & & $* * *$ & & & $* *$ \\
\hline \multicolumn{10}{|l|}{ Contrasts } \\
\hline \multicolumn{3}{|c|}{ Control versus amendment } & $*$ & & & NS & & & NS \\
\hline \multicolumn{3}{|c|}{ Fertilizer versus mulch } & NS & & & NS & & & NS \\
\hline \multicolumn{3}{|c|}{ AS versus NW } & NS & & & * & & & NS \\
\hline \multicolumn{3}{|c|}{$\mathrm{PN}$ versus $\mathrm{MC} \mathrm{SC}$} & $* * *$ & & & $* * *$ & & & $* *$ \\
\hline \multicolumn{3}{|c|}{$\mathrm{MC}$ versus $\mathrm{SC}$} & $* * *$ & & & NS & & & * \\
\hline
\end{tabular}

${ }^{\mathrm{z}} \mathrm{Control}=$ no amendment; $\mathrm{AS}=$ ammonium sulphate; $\mathrm{NW}=$ pelletized poultry manure; $\mathrm{PN}=$ pine needles; $\mathrm{MC}=$ manure and sawdust compost; $\mathrm{SC}=$ seafood waste compost.

${ }^{\mathrm{y}}$ Values are means with $n=5 \pm \mathrm{SD}$. Weed cover rating (average percent area covered by weeds within three $0.25 \mathrm{~m}^{2}$ quadrats per plot): $0=$ no weeds; $1=1 \%$ to $10 \% ; 2=11 \%$ to $20 ; 3=21 \%$ to $30 \% ; 4=31 \%$ to $40 \% ; 5=41-50 ; 6=51 \%$ to $60 \% ; 7=61 \%$ to $70 \% ; 8=71 \%$ to $80 \% ; 9=81 \%$ to $90 \% ; 10=91 \%$ to $100 \%$. ${ }^{\mathrm{x}}$ Values are means with $\mathrm{n}=5$.

NS, $*, * *, * * *$ Nonsignificant or significant at $P \leq 0.05,0.01$, and 0.001 , respectively.

both years and included common lamb'squarters (Chenopodium album L.), sheep sorrel (Rumex acetosella L.), tufted vetch (Vicia cracca L.), common ragweed (Ambrosia artemisiifolia L.), clover (Trifolium spp.), and grasses such as foxtail (Setaria spp.) and barnyardgrass [Echinochloa crus-galli (L.) Beauv.] (Table 5). Although in general, species composition was similar in both years, the relative biomass of common weed species demonstrated a pronounced shift of species proliferation under certain treatments. Lambsquarters dominated species composition in SC but was largely absent in $\mathrm{MC}$ and all other treatments in both years, whereas common ragweed was very prevalent in MC ( $87 \%$ of biomass) in 2006 alone. Sheep sorrel was largely absent in the compost treatments in both years but much more prevalent in all other treatments (up to 58\% of biomass in PN). Legumes (tufted vetch and clover combined) represented $40 \%$ to $60 \%$ of biomass in all treatments except SC in 2005 but were less dominant in all treatments in 2006. Grasses averaged less than $20 \%$ of biomass for all treatments and years (Table 5).

Blueberry leaf nutrient concentration. The amendments used in this study had a significant impact on leaf tissue N, phosphorus (P), and potassium (K) (Table 6). In 2005, mulch application increased leaf tissue $\mathrm{N}$ over the control and fertilized (AS and NW) plots (1.27 versus $1.45 \%$ ). In 2006 (Trial 2), this response to mulches was detected exclusively in weeded subplots and leaf tissue $\mathrm{N}$ concentration decreased in the order SC $(1.51 \%)>$ MC $(1.34 \%)>$ PN $(1.25 \%)$. In Trial $1_{R}$, amendments did not affect leaf tissue N. Instead, the absence of weeds decreased the leaf $\mathrm{N}$ concentration compared with weeded treatment (1.34 versus $1.42 \%)$ in this trial. In general, leaf tissue $\mathrm{P}$ concentrations followed the pattern observed for $\mathrm{N}$ and were significantly higher in mulched plots compared with control and AS and NW treatments and in the year of amendment application only $(0.076 \%$ versus $0.067 \%$ in 2005; Table 6). In 2006 (Trial 2), leaf tissue $P$ in PN was significantly lower than the two compost treatments $(0.064 \%$ versus $0.730 \%)$. As for leaf tissue K, compost mulched plots resulted in significantly higher tissue $\mathrm{K}$ levels than the control and AS and NW treatments in $2005(0.412 \%$ versus $0.363 \%)$ and 2006 $(0.408 \%$ versus $0.350 \%)$, respectively. PN resulted in the lowest leaf tissue $\mathrm{K}$ in every trial year (average $0.312 \%$ ).

Canopy volume, berry yield, and fruit quality. Weed removal significantly increased canopy volume of blueberry bushes in both application years by an average of $16 \%$ over nonweeded subplots (Table 7). In the carryover year (Trial $1_{\mathrm{R}}$,), weeding resulted in significantly greater (38\%) canopy volumes compared with nonweeded subplots. Amendments had no effect on canopy volume in either Trial 1 or Trial 2. In Trial $1_{R}$, the canopy volume of plants mulched in the previous year was $34 \%$ higher than for AS and NW treatments.

There were no significant effects of amendments or groundcover management on berry yield or average berry weight in 2005 (Table 7). There was a significant interaction between amendments and groundcover management for berry number as a result of $85 \%$ higher number of berries found in SC compared with $\mathrm{MC}$ in nonweeded plots (Table 7). In contrast, there were significant amendment and weed management interaction effects for all berry parameters in 2006 . When weeds were not a factor, berry yield was $310 \%$ and berry number $263 \%$ higher in amended subplots compared with the control. Both yield and berry number were 59\% higher in the two compost treatments than in PN (Table 7). In nonweeded subplots, berry yield and number were $327 \%$ and $257 \%$ higher, respectively, in mulched plots compared with AS and NW treatments. Individual berries were $25 \%$ heavier in amended subplots compared with the control and $24 \%$ heavier in mulched subplots than for
AS and NW treatments when hand-weeding was not performed. Yields and berry number for PN were closer, but still lower, than that obtained for both composts (MC and SC) when weeds were present than when absent.

In Trial $1_{R}$, competition from weeds severely reduced yield component parameters (Table 7), including fresh fruit yield by $92 \%$, berry number by $91 \%$, and berry weight by $21 \%$. Amendments had no significant effect on yield component parameters. Plants mulched with PN and SC had the highest and lowest yield (159.5 and $39.1 \mathrm{~g} / \mathrm{bush}$ ) and berry number ( 57.9 and 14.3 berries), respectively (Table 7).

Among berry composition parameters, total phenolics content was unaffected by the various amendment treatments in weeded subplots in the carryover year (Trial $1_{R}$ ) (Table 8). The SC compost supplied the sweetest berries $\left(12.8^{\circ} \mathrm{Brix}\right)$, whereas berries from MC had the lowest sugar content (11.3 ${ }^{\circ}$ Brix).

\section{Discussion}

Weed cover, biomass, and species composition. The importance of weed control in HBB fields was confirmed in this study by the detrimental effects of weed competition on plant growth, nutrient uptake, and productivity. The reduction in canopy volume in all site years resulting from a lack of vegetation management was consistent with the findings of NeSmith and Krewer (1995), who reported that vegetation-free areas of $0.6 \mathrm{~m}^{2}$ and $1.8 \mathrm{~m}^{2}$ surrounding rabbiteye blueberry bushes resulted in significantly greater growth indices compared with areas with no weed control. The number of flower buds per bush was positively correlated with weed control, attributed to the negative effect of reduced plant vigor on flower bud formation. In the present study, the lack of handweeding caused a reduction in berry yield components in both trials (Trial 2 and Trial $\left.1_{R}\right)$ in 2006 with weeds affecting yield 
Table 5. Relative aboveground biomass (fresh weight) of weed species as influenced by amendment treatment.

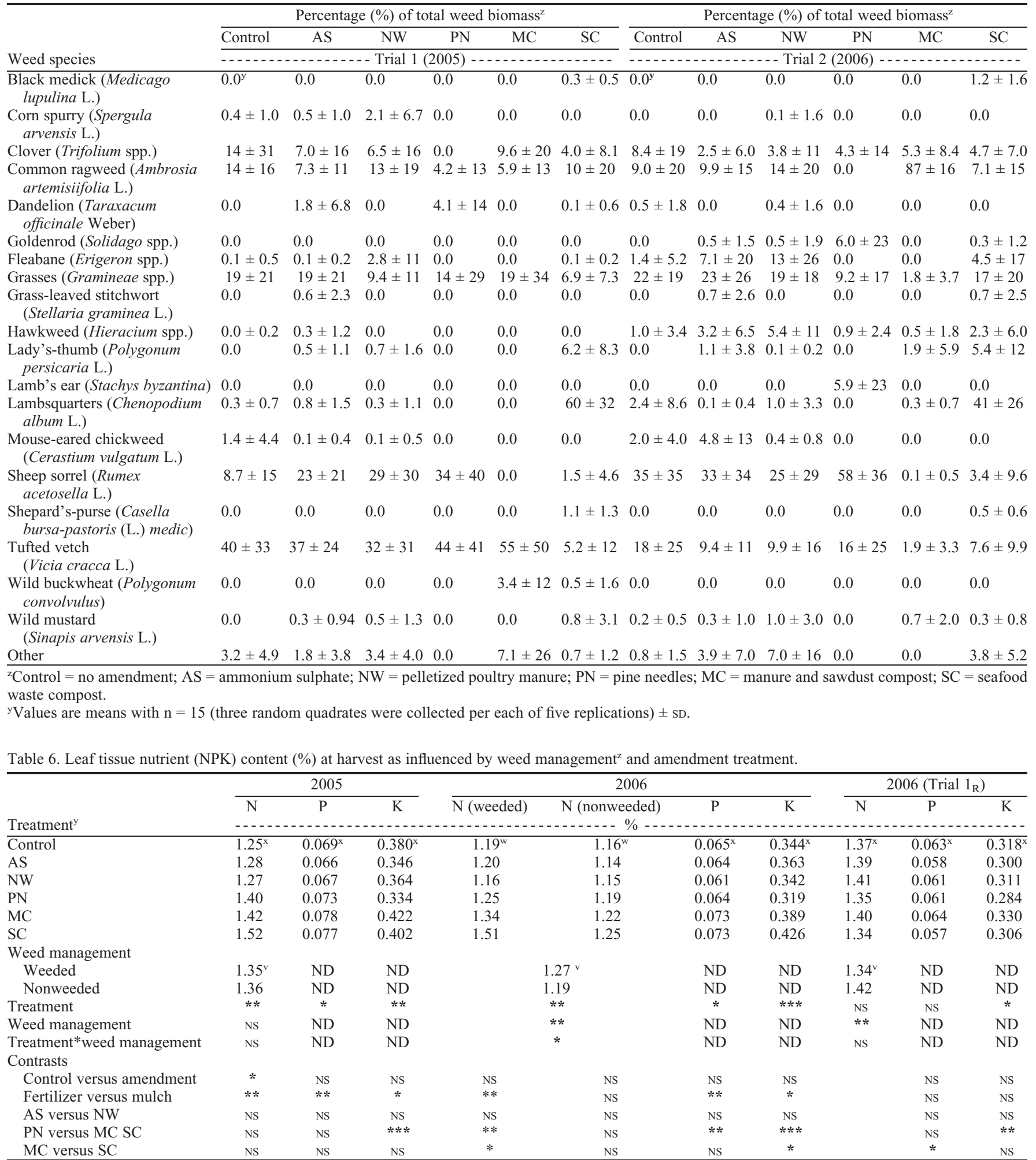

${ }^{\mathrm{z}}$ Weed effect determined for leaf $\mathrm{N}$ content only.

${ }^{\mathrm{y}} \mathrm{Control}=$ no amendment; $\mathrm{AS}=$ ammonium sulphate; $\mathrm{NW}=$ pelletized poultry manure; $\mathrm{PN}=$ pine needles; $\mathrm{MC}=$ manure and sawdust compost; $\mathrm{SC}=$ seafood waste compost.

$\mathrm{x}, \mathrm{w}, \mathrm{v}$ Values are means with ${ }^{\mathrm{x}} \mathrm{n}=10,{ }^{\mathrm{w}} \mathrm{n}=5$, and ${ }^{\mathrm{v}} \mathrm{n}=30$.

NS, * **, ***Nonsignificant or significant at $P \leq 0.05,0.01$, and 0.001 , respectively.

$\mathrm{ND}=$ not determined.

and berry number to a greater extent than amendment treatment effects. However, yield components recorded in 2005 were unaffected by weed management. The prominent effect of weeds in 2006 was also evident in leaf tissue samples, which caused a reduction in leaf tissue $\mathrm{N}$ in nonweeded subplots, although complicated by amendment-ground floor management interactions. In apple orchards, competition with sod groundcover has consistently resulted in lower concentrations of leaf N (Hogue and Neilsen, 1987).

It appears that the capacity of weeds to reduce yields cannot simply be explained by total aboveground weed biomass at harvest. 


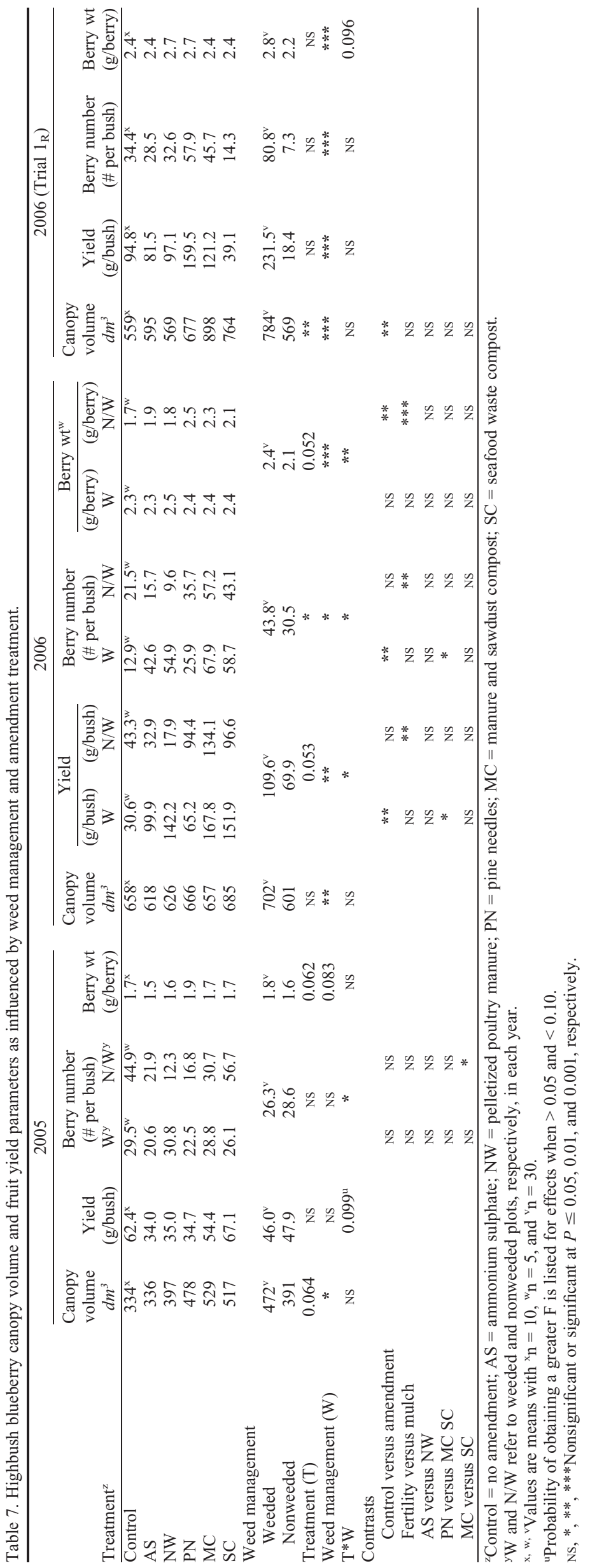

This yield reduction may be attributed to vigorous weed roots competition with the superficial fibrous root systems of HBB (NeSmith and Krewer, 1995). Midseason weed cover surveys demonstrated greater weed coverage earlier in the season in 2006 than in 2005. The prominent impact of weeds on crop productivity in 2006 may have been attributed to earlier emergence of weeds as a result of more favorable growing conditions such as warmer air temperatures and more frequent precipitation. In 2006, the onset of air temperatures above $10{ }^{\circ} \mathrm{C}$ took place in early May, yet in 2005, this was delayed until early June. Also, rainfall was $66 \%$ higher in June and July of 2006 compared with the same period in 2005. Weed control is most crucial early in the season (Hanson and Havens, 1992; Sciarappa et al., 2008), and it has even been proposed that late-season weed growth could actually be beneficial to blueberry plants by removing excess $\mathrm{N}$ and encouraging the plants to "harden off" for the winter (Hanson and Havens, 1992).

In the present study, in-row vegetation was effectively suppressed by PN and, to a lesser degree, by MC. The difference in weed control by MC between years was a result of weed seeds (predominantly common ragweed) that proliferated in MC in Trial 2, demonstrating the variation of weed seedbank that can occur in composts from 1 year to the next. Both composts, MC and SC, were successful at suppressing some dominant perennial weeds (namely sheep sorrel). The major factor that influenced weed suppression by the compost mulches for certain weed species was likely mulch thickness and bulk density, which provided a physical barrier to weed growth and prevented light penetration to the soil surface. Otherwise, the compost mulches, especially SC, provided an ideal texture and nutrient-rich growing media for weeds to proliferate. The germination of weed seeds in this study, in particular lamb's-quarters and common ragweed in SC and MC treatments, respectively, negated the ability of these treatments to provide adequate weed control. These results may have been the result of these treatments not being composted under sustained thermophilic temperatures (Grundy et al., 1998; Thompkins et al., 1998) and/or the treatments not being covered during the maturation process resulting in recontamination of the pile.

Sheep sorrel is a calcifuge weed species and thus its suppression by SC and MC, but not $\mathrm{PN}$, could also have been influenced by the $\mathrm{pH}$ of the organic mulches and/or their affect on soil acidity. Changes in $\mathrm{pH}$ of surface $(0$ to $6 \mathrm{~cm})$ soil were observed only in the two compost treatments with increases of 0.8 units (from 5.4 to 6.2) and 0.4 units (5.4 to 5.8) for SC and MC, respectively (data not shown). In a half-high blueberry trial, Shanmugam (2005) reported similar (0.4-unit) increases in soil $\mathrm{pH}$ as a result of the application of manure and municipal composts. It could be expected that PN mulch may acidify the soil over time and alter the species composition toward more acid-tolerant 
Table 8 . Berry quality as influenced by amendment treatments in the year after application (Trial $1_{R}$ ).

\begin{tabular}{lcc}
\hline Treatment & $\begin{array}{c}\text { Soluble solids } \\
\left({ }^{\circ} \text { Brix }\right)\end{array}$ & $\begin{array}{c}\text { Total phenolics gallic acid equivalents } \\
\left(\mathrm{mg} \cdot \mathrm{g}^{-1} \text { fresh wt }\right)\end{array}$ \\
\hline Control & $12.2^{\mathrm{y}}$ & $3.43^{\mathrm{y}}$ \\
$\mathrm{AS}$ & 12.4 & 3.60 \\
$\mathrm{NW}$ & 12.1 & 3.44 \\
$\mathrm{PN}$ & 11.7 & 2.99 \\
$\mathrm{MC}$ & 11.3 & 3.34 \\
SC & 12.8 & 3.65 \\
Treatment & $*$ & $\mathrm{NS}$ \\
Contrasts & & \\
$\quad$ Control versus amendment & $\mathrm{NS}$ & \\
$\quad$ Fertilizer versus mulch & $\mathrm{NS}$ & \\
$\quad$ AS versus NW & $\mathrm{NS}$ & \\
$\quad$ PN versus MC SC & $\mathrm{NS}$ & \\
MC versus SC & $* *$ & \\
\hline
\end{tabular}

${ }^{{ }^{z}} \mathrm{Control}=$ no amendment $; \mathrm{AS}=$ ammonium sulphate $; \mathrm{NW}=$ pelletized poultry manure $; \mathrm{PN}=$ pine needles; $\mathrm{MC}=$ manure and sawdust compost $\mathrm{SC}=$ seafood waste compost.

${ }^{y}$ Values are means with $\mathrm{n}=5$.

NS, $* * *, * * *$ Nonsignificant or significant at $P \leq 0.05,0.01$, and 0.001 , respectively.

weeds. Duryea et al. (1999) reported that a 9$\mathrm{cm}$ layer of pine straw mulch caused a reduction in $\mathrm{pH}$ from 5.0 to 4.4 after 1 year during a landscape trial, whereas Makus et al. (1994) found $\mathrm{pH}$ dropped by 0.56 units in an okra field mulched with pine needle straw.

The PN treatment may have also suppressed weed emergence resulting from the release of allelopathic compounds preventing seed germination and impairing plant growth. Duryea et al. (1999) found that leachate from fresh, 3-month- and 1-year-old pine straw mulch inhibited germination of lettuce seeds and contained hydroxylated aromatic compounds, which could have contributed to its allelopathic action.

Overall, mulch treatments, with the exception of $\mathrm{PN}$, were less effective in reducing weed growth in the year after application (Trial $1_{R}$ ). Weed proliferation was expectedly more rapid and aggressive than in the first year because perennial weeds were more established and as a result of the seed load from annual species. Similar results were reported by Brown and Tworkoski (2004) in apple production systems and reiterate the observation that although effective in reducing weed pressures in the year of application, composted manures did not reduce weed cover in the carryover year. Mulch thickness may have been a contributing factor to this effect as a result of weed seedling emergence being directly related to mulch thickness (Aldrich, 1984; Ozores-Hampton, 1998). All mulches experienced varying degrees of decomposition and subsistence throughout the year, resulting in reduced mulch thickness in the next year. It may be necessary to reapply mulches yearly to maintain mulch thickness and continue any weed control benefit. This is especially relevant for PN because it experienced the greatest height reduction and provided the best weed control of the three mulches.

Amendment impact on highbush blueberry productivity and berry composition. Results obtained in this study indicate that benefits to plant productivity were achieved from the use of surface-applied mulches. Although benefits of $\mathrm{PN}$ were primarily related to more effective weed control, plant nutrition as reflected by leaf tissue NPK analysis and productivity (vegetative growth, yields, berry number and size) was typically higher for mulch treatments. Yield benefits associated with composts, however, were substantially reduced in non-weeded compared with weeded treatments, by $20 \%$ to $35 \%$ in 2006 , whereas 2006 yields under PN were unaffected. Similar HBB canopy volume results attributed to the use of composted mulches observed in this study were reported previously by Goulart et al. (1997) with the use of composted sawdust mulch and the cv. Bluecrop. The results obtained in this study are also consistent with those of Haynes and Swift (1986) in which various combinations of crushed pine bark, peat, and elemental sulfur tended to result in greater plant size and fruit yield compared with unmulched plots. The mulch treatments may contribute to positive effects with regard to root growth (Spiers, 1986), increased moisture retention, and enhanced growth as a result of higher overall nutrient levels. Highbush blueberries are generally very susceptible to water stress.

Results obtained for berry yield (ranging from $34.7 \mathrm{~g} /$ plant to $160 \mathrm{~g} /$ plant) were in the lower end of the range found in the literature, whereas berry number (ranging from 14.3 to 62.6 berries per plant) values were comparatively less. Shanmugam (2005) reported the range of $50 \mathrm{~g} /$ plant to $280 \mathrm{~g} /$ plant total yield for 3-year-old half-high blueberries in Nova Scotia, Canada. Eck and Stretch (1986) reported total berry yields of between 148.7 g/plant (low N rate) and $173 \mathrm{~g} /$ plant (high $\mathrm{N}$ rate) for 3-year-old 'Earliblue' bushes, whereas berry number averaged 146.5 berries per plant. In Michigan, Hanson and Retamales (1992) reported yields for 9-year-old 'Bluecrop' of $374 \mathrm{~g} /$ plant. The HBB yields reported by Townsend (1973) ranged from 180 to $389 \mathrm{~g} /$ plant in the fourth year after transplanting and increased to 1077 to 1472 $\mathrm{g} /$ plant by the sixth year after transplanting. Magee and Spiers (1995) measured an average of 8.7 times lower yields at 3 years compared with 5 years after transplanting of HHB (315 versus 2737 g/plant). The low berry yield and number in our study could have been attributed to the younger age of the plants, having not yet reached their full production potential. In 2005, plants were in their fourth season ( 3 years old) and in 2006, they were in their fifth season (4 years old), whereas regionally full production potential is reached with greater than 5-year-old plants. In contrast, average berry weight recorded (ranging from 1.58 to $2.61 \mathrm{~g}$ per berry) exceeded values found in the literature and is attributable, at least partially, to an inverse relationship between berry weight and number (Siefker and Hancock, 1986). In other words, the larger size of berries may be attributed to lower yields and crop load in these organic HBBs. Prior et al. (1998), in New Jersey, found average berry weight of 'Duke' plants to be $1.10 \mathrm{~g}$. In a study conducted in Maryland, the largest berry weight for 'Bluecrop' plants was $1.30 \mathrm{~g}$ (Black and Zimmerman, 2002).

In general, leaf tissue $\mathrm{N}$ values (ranging from $1.16 \%$ to $1.52 \%$ ) were below a suggested sufficiency threshold of $1.7 \% \mathrm{~N}$ (Hanson et al., 1992). The cause of the low $\mathrm{N}$ values could be related to the sampling date of early to mid-Aug., $\approx 2$ weeks after the beginning of harvest. Pliszka et al. (1993) proposed an optimal leaf $\mathrm{N}$ value of $1.3 \%$ to $1.4 \%$ for leaves collected after harvest. Regardless of mulch quality, nutrient immobilization does not appear to be a factor in the present study when leaf nutrient concentrations in mulch treatments were compared with the control, or other studies noted previously, in which the mulches were surface-applied to $\mathrm{HBB}$ and not soil-incorporated. In contrast, overfertilization, as evidenced by vigorous HBB vegetative (and weed) growth, may have been a cause of low berry yields for SC in the carryover year in particular (Gough, 1994). Few differences were observed between the two fertility treatments, NW and AS, in yield, vegetative growth, or leaf tissue $\mathrm{N}$ levels and the unfertilized control, either indicating that the addition of $\mathrm{N}$ at these rates was too low or that the timing of application was too early in the season to induce plant response. Fertility treatments were applied between budbreak and bloom, at which time HBB growth rates are slow and plant $\mathrm{N}$ demand is low (Throop and Hanson, 1998). In Trial $1_{R}$, weeds had a great impact on plant growth (i.e., canopy volume). This likely reduced a dilution effect of growth on leaf $\mathrm{N}$ concentration and consequently lower leaf $\mathrm{N}$ was measured in weeded compared with nonweeded treatments.

Overall, total soluble solid levels were greater than those observed by Prior et al. (1998), who reported a value of $10.0^{\circ}$ Brix for 'Duke' berries. The lower levels of soluble solids found in berries from PN and MC compared with SC treatments were inversely related to greater yields associated with these treatments in Trial $1_{\mathrm{R}}$. Similar trends were reported by Ballinger et al. (1963) and were partially attributable to competition for photosynthates and not $\mathrm{N}$ fertilization. Therefore, the variation in fruit sugar content 
observed in the mulch treatments was likely not a direct result of differences in $\mathrm{N}$ nutrition. The total phenolics content of blueberries varies depending on genetic factors and environmental conditions (Connor et al., 2002). The understanding of the impacts of environmental factors such as mulch on phenolic content of berries is very limited and more research is needed to establish these relationships.

\section{Summary and Conclusions}

Competition from weeds was found to negatively affect HBB growth and productivity, resulting in reduced canopy volumes, leaf $\mathrm{N}$ concentration, and lower berry yields. These results were even more pronounced after 2 years without weed control. Among mulches, PN proved to be the most effective treatment in suppressing weed growth for HBB with $55 \%$ and $73 \%$ less aboveground weed biomass compared with the control in 2005 and 2006, respectively. One year after application, the PN mulch lost some efficacy at suppressing weeds but was still superior to both composts. Therefore, it would be recommended to continue to topdress $\mathrm{PN}$ or similar mulches on a yearly basis to maintain mulch thickness. Suppression of some dominant perennial weeds by MC and SC, likely as a result of their thickness and bulk density, suggests that composts can be used as mulches for weed control.

Plant productivity was typically higher when thick applications of mulch were applied despite high $\mathrm{C}: \mathrm{N}$ ratios of $\mathrm{PN}$ and MC (72:1 and 48:1, respectively). The differences in yield, vegetative growth, or leaf tissue $\mathrm{N}$ levels in response to fertility treatments (NW and AS) compared with the unfertilized control were mostly not significant. Soluble solid (sugar) content was found to be lower in PN and MC compared with SC, which could have been a dilution effect caused by higher crop load. Weed removal enhanced these benefits but had less of an impact in PN plots where weeds were substantially reduced. Composts also provided more complete fertilization, including $\mathrm{N}, \mathrm{P}$, and $\mathrm{K}$, which was reflected in leaf tissue elemental composition.

Overall, mulch application can maintain and improve organic HBB productivity by improving soil chemical and physical properties (composts), nutrient availability (composts), and weed suppression (PN). This approach can be cost-effective depending on local availability of mulch materials. However, precautions should be taken to avoid excess nutrients from heavy application of nutrient-rich mulches and weed seed contamination of these types of mulch. NutriWave pelletized poultry manure produced similar results to ammonium sulphate fertilizer, indicating the possibility of its use as a suitable fertilizer alternative for organic HBB productions. More research is needed to evaluate the long-term effects of different mulches on productivity and nutrient availability in these systems. In addition, testing a combination of nutrient-rich mulches (i.e., $\mathrm{MC}$ and SC) with weed-suppressing mulches (i.e., PN) would be beneficial. The effects of mulch on mycorrhizal fungi infection, disease and pest management are other aspects needing further investigation.

\section{Literature Cited}

Aldrich, R.J. 1984. Weed-crop ecology: Principles in weed management. Breton Publishers, North Scituate, MA.

Ballinger, W.E., L.J. Kushman, and J.F. Brooks. 1963. Influence of crop load and $\mathrm{N}$ applications on the yield and fruit quality of 'Wolcott' blueberries. Proc. Amer. Soc. Hort. Sci. 88: 264-276.

Black, B.L. and R.H. Zimmerman. 2002. Mixtures of coal ash and compost as substrates for highbush blueberry. J. Amer. Soc. Hort. Sci. 127:869-877.

Bond, W. and A.C. Grundy. 2001. Non-chemical weed management in organic farming systems. Weed Res. 41:383-405.

Brown, M.W. and T. Tworkoski. 2004. Pest management benefits of compost mulch in apple orchards. Agr. Ecosyst. Environ. 103:465-472.

Caamal-Maldonado, J.A., J.J. Jimenez-Osornio, A Torres-Barragan, and A.L. Anaya. 2001. The use of allelopathic legume cover and mulch species for weed control in cropping systems. Agron. J. 93:27-36.

Canadian General Standards Board/Standards Council of Canada. 2006. Organic production systems general principles and management standards. National standard of Canada. CAN/ CGSB-32.310-2006. Canadian General Standards Board, Gatineau, Quebec, Canada.

Connor, A.M., J.J. Luby, and C.B.S. Tong. 2002 Genotypic and environmental variation in antioxidant activity, total phenolic content, and anthocyanin content among blueberry cultivars. J. Amer. Soc. Hort. Sci. 127:89-97.

Duryea, M.L., R.J. English, and L.A. Hermansen. 1999. A comparison of landscape mulches: Chemical, allelopathic, and decomposition properties. J. Arboric. 25:88-96.

Eck, P. and A.W. Stretch. 1986. Nitrogen and plant spacing effects on growth and fruiting of potted highbush blueberry. HortScience 21: 249-250.

Environment Canada. 2007. Canadian climate normals, Kentville, NS (1961-1990). 12 Mar. 2007. <http://www.climate.weatheroffice.ec.gc. ca/climate_normals/results_1961_1990_e/>.

Gough, R.E. 1994. The highbush blueberry and its management. Food Products Press, New York, NY

Goulart, B.L., K. Demchak, and W.Q. Yang. 1997. Effect of cultural practices on field grown 'Bluecrop' highbush blueberries, with emphasis on mycorrhizal infection levels. Acta Hort. 446:271-278

Granatstein, D. and K. Mullinix. 2008. Mulching options for northwest organic and conventional orchards. HortScience 43:45-50

Grundy, A.C., J.M. Green, and M. Lennartsson. 1998. The effect of temperature on the viability of weed seeds in compost. Compost Sci. Util. 6:26-33.

Hanson, E.J., J. Hart, and B. Strik. 1992. Nutrient management, p. 99-109. In: Pritts M.P. and J.F Hancock (eds.). Highbush blueberry production guide. Northeast Regional Agricultural Engineering Service, Ithaca, NY.

Hanson, E.J. and D. Havens. 1992. Weed management, p. 95-98. In: Pritts M.P. and J.F. Hancock (eds.). Highbush blueberry production guide.
Northeast Regional Agricultural Engineering Service, Ithaca, NY.

Hanson, E.J. and J.B. Retamales. 1992. Effect of nitrogen source and timing on highbush blueberry performance. HortScience 27:1265-1267.

Haynes, R.J. and R.S. Swift. 1986. Effect of soil amendments and sawdust mulching on growth, yield and leaf nutrient content of highbush blueberry plants. Sci. Hort. 29:229-238.

Hendershot, W.H., H. Lalande, and M. Duquette. 1993. Soil reaction and exchangeable acidity, p. 141-146. In: Carter, M.R. (ed.). Soil sampling and methods of analysis. Lewis Publishers, Boca Raton, FL.

Hogue, E.J. and G.H. Neilsen. 1987. Orchard floor vegetation management. Hort. Rev. (Amer. Soc. Hort. Sci.) 9:377-430.

Holmstrom, D.A. and B.L. Thompson. 1989. Soils of the Annapolis Valley area of Nova Scotia. Report No 22 Nova Scotia Soil Survey. Agriculture Development Branch, Agriculture Canada.

Kozinski, B. 2006. Influence of mulching and nitrogen fertilization rate on growth and yield of highbush blueberry. Acta Hort. 715:231-236.

Kuepper, G.L. and S. Diver. 2004. Blueberries: Organic production. 1 Apr. 2005. $<\mathrm{http}: / / \mathrm{www}$. attra.ncat.org/>.

Lord, W. 1992. Establishing the blueberry planting, p. 34-36. In: Pritts M.P. and J.F. Hancock (eds.). Highbush blueberry production guide. Northeast Regional Agricultural Engineering Service, Ithaca, NY.

Lynch, D.H., R.P. Voroney, and P.R. Warman. 2004. Nitrogen availability from composts for humid region perennial grass and legume-grass forage production. J. Environ. Qual. 33:15091520

Lynch, D.H., Z. Zheng, B.J. Zebarth, and R.C. Martin. 2008. Organic amendment effects on tuber yield, plant $\mathrm{N}$ uptake and soil mineral $\mathrm{N}$ under organic potato production. Renewable Agr. Food Systems 23:250-259.

Magee, J.B. and J.M. Spiers. 1995. Influence of mulching systems on yield and quality of southern highbush blueberries. J. Small Fruit Vitic. 3:133-141.

Makus, D.J., S.C. Tiwari, H.A. Pearson, J.D. Haywood, and A.E. Tiarks. 1994. Okra production with pine straw mulch. Agrofor. Syst. 27:121-127.

NeSmith, D.S. and G. Krewer. 1995. Vegetationfree area influences growth and establishment of rabbiteye blueberry. HortScience 30:14101412.

Ozores-Hampton, M. 1998. Compost as an alternative weed control method. HortScience 33:938-940.

Percival, D. 2006. Levels and distribution of anthocyanins, proanthocyanidins, flavonols, and hydroxycinnamic acids in Vaccinium angustifolium Aiton cv. 'Fundy'. Acta Hort. 715:595-601.

Pliszka, K., K. Scibisz, and H. Rojek. 1993. The effect of soil management and mineral fertilization upon growth and cropping of the highbush blueberry cv. Bluecrop. Acta Hort. 346: 149-154.

Prior, R.L., C. Guohua, A. Martin, E. Sofic, J. McEwan, C. O'Brien, N. Lischner, M. Ehlenfeldt, W. Kalt, G. Krewer, and C.M. Mainland. 1998. Antioxidant capacity as influenced by total phenolic and anthocyanin content, maturity, and variety of Vaccinium species. J. Agr. Food Chem. 46:2686-2693.

Sciarappa, W., S. Polavarapu, J. Barry, P. Oudemans, M. Ehlenfeldt, G. Pavlis, D. Polk, and R. Holdcraft. 2008. Developing an organic production system for highbush blueberry. HortScience 43:51-57. 
Shanmugam, S.G. 2005. Soil and plant response of organic amendments on strawberry and halfhigh blueberry cultivars, Dalhousie Univ, Halifax, Canada. MSc Diss.

Siefker, J.H. and J.F. Hancock. 1986. Yield component interactions in cultivars of the highbush blueberry. J. Amer. Soc. Hort. Sci. 111:606608 .

Slinkard, K. and V.L. Singleton. 1977. Total phenolic analysis: Automation and comparison with manual methods. Amer. J. Enol. Viticult. 28:49-55.

Spiers, J. 1986. Root distribution of 'Tifblue' rabbiteye blueberry as influenced by irrigation, incorporated peatmoss, and mulch. J. Amer. Soc. Hort. Sci. 111:877-880.

Strik, B. 2006. Blueberry production and research trends in North America. Acta Hort. 715:173183.

Strik, B. and J. Hart. 1997. Fertilizer guide: Blueberries. Oregon State Extension Service. FG 78.

Thompkins, D.K., D. Chaw, and A.T. Abiola 1998. Effect of windrow composting on weed seed germination and viability. Compost Sci. Util. 6:30-34.

Throop, P.A. and E.J. Hanson. 1998. Nitrification and utilization of fertilizer nitrogen by highbush blueberry. J. Plant Nutr. 21:1731-1742.
Townsend, L.R. 1973. Effects of soil amendments on the growth and productivity of the highbush blueberry. Can. J. Plant Sci. 53: 571-577.

Yang, W.Q., B.L. Goulart, K. Demchak, and Y. Li. 2002. Interactive effects of mycorrhizal inoculation and organic soil amendments on nitrogen acquisition and growth of highbush blueberry. J. Amer. Hort. Sci. 127:742-748.

Zheljazkov, V.D. and P.R. Warman. 2002. Comparison of three digestion methods for the recovery of 17 plant essential nutrients and trace elements from six composts. Compost Sci. Util. 10:197-203. 